\title{
Mesomorphic Behavior in Silver(I) N-(4-Pyridyl) Benzamide with Aromatic $\pi-\pi$ Stacking Counterions
}

\author{
Issac Torres ${ }^{1}$, Mauro Ruiz ${ }^{1}$, Hung Phan 2 ${ }^{\circledR}$, Noemi Dominguez ${ }^{1}$, Jacobo Garcia ${ }^{1}$, \\ Thuc-Quyen Nguyen ${ }^{2}$, Hayden Evans ${ }^{2}$, Marino J. Resendiz ${ }^{3}{ }^{-}$, Tunna Baruah ${ }^{4}$, \\ Alejandro Metta ${ }^{1}$, Atta Arif ${ }^{5}$ and Juan C. Noveron ${ }^{1, *}$ \\ 1 Department of Chemistry, University of Texas at El Paso, El Paso, TX 79968, USA; \\ igtorres@miners.utep.edu (I.T.); mjruiz@miners.utep.edu (M.R.); \\ ndominguez6@miners.utep.edu (N.D.); jegarcia1524@gmail.com (J.G.); ajmetta@utep.edu (A.M.) \\ 2 Department of Chemistry \& Biochemistry, University of California Santa Barbara, \\ Santa Barbara, CA 93106-9510, USA; hphan@chem.ucsb.edu (H.P.); \\ quyen@chem.ucsb.edu (T.-Q.N.); hevans@chem.ucsb.edu (H.E.) \\ 3 Department of Chemistry, University of Colorado, Denver, CO 80217-3364, USA; \\ MARINO.RESENDIZ@UCDENVER.EDU \\ 4 Department of Physics, University of Texas at El Paso, El Paso, TX 79968, USA; tbaruah@utep.edu \\ 5 Department of Chemistry, University of Utah, Salt Lake City, UT 84112, USA; arif@chemistry.utah.edu \\ * Correspondence: jcnoveron@utep.edu
}

Received: 20 June 2018; Accepted: 3 September 2018; Published: 9 September 2018

\begin{abstract}
Organic semiconductor materials composed of $\pi-\pi$ stacking aromatic compounds have been under intense investigation for their potential uses in flexible electronics and other advanced technologies. Herein we report a new family of seven $\pi-\pi$ stacking compounds of silver(I) bis- $\mathrm{N}$-(4-pyridyl) benzamide with varying counterions, namely [Ag(NPBA)2]X, where NPBA is $\mathrm{N}$-(4-pyridyl) benzamine, $\mathrm{X}=\mathrm{NO}_{3}{ }^{-}$(1), $\mathrm{ClO}_{4}{ }^{-}$(2), $\mathrm{CF}_{3} \mathrm{SO}_{3}{ }^{-}$(3), $\mathrm{PF}_{6}{ }^{-}$(4), $\mathrm{BF}_{4}^{-}$(5), $\mathrm{CH}_{3} \mathrm{PhSO}_{3}{ }^{-}$ (6), and $\mathrm{PhSO}_{3}{ }^{-}$(7), which form extended $\pi-\pi$ stacking networks in one-dimensional (1D), $2 \mathrm{D}$ and $3 \mathrm{D}$ directions in the crystalline solid-state via the phenyl moiety, with average inter-ring distances of $3.823 \AA$. Interestingly, the counterions that contain $\pi-\pi$ stacking-capable groups, such as in $\mathbf{6}$ and 7 , can induce the formation of mesomorphic phases at $130{ }^{\circ} \mathrm{C}$ in dimethylformamide (DMF), and can generate highly branched networks at the mesoscale. Atomic force microscopy studies showed that $2 \mathrm{D}$ interconnected fibers form right after nucleation, and they extend from $\sim 30 \mathrm{~nm}$ in diameter grow to reach the micron scale, which suggests that it may be possible to stop the process in order to obtain nanofibers. Differential scanning calorimetry studies showed no remarkable thermal behavior in the complexes in the solid state, which suggests that the mesomorphic phases originate from the mechanisms that occur in the DMF solution at high temperatures. An all-electron level simulation of the band gaps using NRLMOL (Naval Research Laboratory Molecular Research Library) on the crystals gave $3.25 \mathrm{eV}$ for (1), $3.68 \mathrm{eV}$ for (2), $1.48 \mathrm{eV}$ for (3), $5.08 \mathrm{eV}$ for (4), $1.53 \mathrm{eV}$ for (5), and $3.55 \mathrm{eV}$ for (6). Mesomorphic behavior in materials containing $\pi-\pi$ stacking aromatic interactions that also exhibit low-band gap properties may pave the way to a new generation of highly branched organic semiconductors.
\end{abstract}

Keywords: mesomorphic materials; metallo-mesogens; silver complexes; $\pi-\pi$ stacking; crystalline solids

\section{Introduction}

Organic semiconductor materials composed of $\pi-\pi$ stacking aromatic compounds have been under intense investigation for their potential uses in flexible electronics [1], field-effect transistors [2,3], light-emitting diodes [4-6], and photovoltaics [7-9]. In organic semiconductors, the electrical charge is transported along the direction of $\pi-\pi$ stacking, and this is highly dependent on the surface area 
and morphology of the material. Due to this phenomenon, architectures that elucidate $\pi-\pi$ stacking interactions and that can induce new morphologies are warranted. Engineering new materials with directional non-covalent interactions is a rapidly growing area [10-13], with the potential to generate novel molecular architectures using hydrogen bonding [14], metal-ligand coordination $[15,16]$, and $\pi-\pi$ stacking interactions [17-22]. In particular, aromatic $\pi-\pi$ stacking interactions can direct the formation of one-dimensional (1D), 2D, and 3D crystalline nanostructures through self-assembly $[23,24]$ and they can serve to engineer the physical properties of organic semiconductors [25-29]. With regard to intermolecular interactions, other factors such as solvents [30-34] and counterions [35-45] have been shown to play key roles in the structure of the final assembly. Therefore, the studies that establish the relationship of supramolecular structures in $\pi-\pi$ stacking architectures can lead to a roadmap of synergistic intermolecular effects that pave the way to the rational design of materials.

Silver (Ag)(I) complexes have been reported to form molecular materials with an assorted set of structural topologies suitable for systematic structural studies [46,47]. For example, variations of the counterions in silver complexes have revealed trends useful in catalysis [48,49], optics [50], and medicine [50,51]. The anion influence in the assembly of silver-complexes is particularly notable [52-57], since the low coordination number and cationic nature of $\mathrm{Ag}(\mathrm{I})$ facilitates the influence of anions during self-organization in the crystalline solid-state. Generally, the anions act either as coordinated, bridging, or non-coordinated void-filling species and their influence on self-assembly is unpredictable.

Herein we carry out a systematic study of the influence of counterions during the formation of non-covalent networks in the crystalline solid state of silver(I) complexes of $\mathrm{N}$-(4-pyridyl) benzamine (NPBA), namely $\left[\mathrm{Ag}(\mathrm{NPBA})_{2}\right] \mathrm{X}$, where $\mathrm{X}=\mathrm{NO}_{3}^{-}(1), \mathrm{ClO}_{4}^{-}{ }^{-}(2), \mathrm{CF}_{3} \mathrm{SO}_{3}^{-}$(3), $\mathrm{PF}_{6}^{-}$(4), $\mathrm{BF}_{4}^{-}$(5), $\mathrm{CH}_{3} \mathrm{C}_{6} \mathrm{H}_{4} \mathrm{SO}_{3}{ }^{-}(6)$, and $\mathrm{C}_{6} \mathrm{H}_{6} \mathrm{SO}_{3}{ }^{-}$(7). This allowed us to correlate supramolecular structures, resulting in $\pi-\pi$ stacking networks of $1 \mathrm{D}, 2 \mathrm{D}$, and $3 \mathrm{D}$ formations in the crystalline solid-state. This study allowed us to discover that $\pi-\pi$ stacking capable counterions, such as those in 6 and 7, form mesomorphic phases at $130{ }^{\circ} \mathrm{C}$ in dimethylformamide (DMF), giving rise to highly branched flexible fibers as small as $\sim 30 \mathrm{~nm}$ in diameter and extended into the micron scale. This mesogenic property induced by $\pi-\pi$ stacking capable counterions, will have important implications in the design of nano- and micro-structured organic semiconductors.

\section{Experimental Section}

Materials: Silver nitrate $\left(\mathrm{Ag}(\mathrm{NO})_{3} \geq 99 \%\right)$, silver perchlorate $\left(\mathrm{AgClO}_{4} 97 \%\right)$, silver trifluoromethanesulfonate $\left(\mathrm{CF}_{3} \mathrm{SO}_{3} \mathrm{Ag} \geq 99 \%\right)$, silver hexafluorophosphate $\left(\mathrm{AgPF}_{6} 98 \%\right)$, silver tetrafluoroborate $\left(\mathrm{AgBF}_{4} 98 \%\right)$, silver p-toluenesulfonate $\left(\mathrm{CH}_{3} \mathrm{C}_{6} \mathrm{H}_{4} \mathrm{SO}_{3} \mathrm{Ag} \geq 99 \%\right)$, $\mathrm{N}$,N-dimethylformamide ( $\left.\mathrm{HCON}\left(\mathrm{CH}_{3}\right)_{2} 99.8 \%\right)$, 1-propanol $\left(\mathrm{CH}_{3} \mathrm{CH}_{2} \mathrm{CH}_{2} \mathrm{OH} 99.7 \%\right)$, methanol $\left(\mathrm{CH}_{3} \mathrm{OH} 99.8 \%\right)$, ethanol $\left(\mathrm{CH}_{3} \mathrm{CH}_{2} \mathrm{OH} \geq 99.8 \%\right)$, diethyl ether $\left(\left(\mathrm{CH}_{3} \mathrm{CH}_{2}\right)_{2} \mathrm{O} \geq 99.7 \%\right)$, and sodium benzene-1,3-disulfonate $\left(\left(\mathrm{C}_{6} \mathrm{H}_{4}\left(\mathrm{SO}_{3} \mathrm{Na}\right)_{2} 80 \%\right)\right.$ were obtained from Sigma-Aldrich, St. Louis, MO, USA. The synthesis of NPBA and $\left[\mathrm{Ag}(\mathrm{NPBA})_{2}\right] \mathrm{NO}_{3}$ have been previously described [49]. The synthesis of 1 was carried out by following a previous reported synthesis [58].

Synthesis of $\left[\mathrm{Ag}(\mathrm{NPBA})_{2}\right]\left(\mathrm{ClO}_{4}\right)$ (2). A solution of NPBA $(20 \mathrm{mg}, 0.10 \mathrm{mmol})$ in $7 \mathrm{~mL}$ methanol was added to a separate solution containing silver perchlorate $(10.7 \mathrm{mg}, 0.05 \mathrm{mmol})$ in $3 \mathrm{~mL}$ of methanol. After constant stirring, a white precipitate appeared and after allowing the mixture to react under stirring for $3 \mathrm{~h}$, the precipitate was filtered. A saturated solution of this complex in DMF was prepared and left for diethyl ether diffusion for $48 \mathrm{~h}$ in the dark, generating colorless prism-shaped crystals that were subsequently filtered and washed with diethyl ether. Yield: $26.8 \mathrm{mg}, 87 \%$; IR $\left(\mathrm{cm}^{-1}\right): 2360,1658,1584$, 1506, 1418, 1331, 1266, 1064, 824, 712, 622. Elemental analysis calculated for $\left[\mathrm{Ag}(\mathrm{NPBA})_{2}\right]\left(\mathrm{ClO}_{4}\right)$ : C, 47.74; H, 3.34; N, 9.28. Found: C, 47.60; H, 3.38; N, 9.14. CCDC (Cambridge Crystallographic Data Centre): 1404799.

Synthesis of $\left[\mathrm{Ag}(\mathrm{NPBA})_{2}\right](\mathrm{OTF}-$ Triflate $)(3)$. A solution of NPBA $(20 \mathrm{mg}, 0.10 \mathrm{mmol})$ in $7 \mathrm{~mL}$ of ethanol was added to a separate solution containing silver triflate $(13.2 \mathrm{mg}, 0.05 \mathrm{mmol})$ in $3 \mathrm{~mL}$ of ethanol. The resulting solution was allowed to stir for $3 \mathrm{~h}$; the precipitate formed was then filtered. 
A saturated solution of the complex in methanol was then prepared and left for diethyl ether diffusion into the reaction mixture for $72 \mathrm{~h}$ in the dark, generating colorless block shaped crystals. These crystals were subsequently collected, filtered, and washed with diethyl ether. Yield: $28.1 \mathrm{mg}, 85 \%$; IR ( $\left.\mathrm{cm}^{-1}\right)$ : $2367,1682,1604,1520,1424,1337,1266,1033$. Elemental analysis calculated for $\left[\mathrm{Ag}(\mathrm{NPBA})_{2}\right](\mathrm{OTF})$ : C, 53.78; H, 3.72; N, 10.35. Found: C, 45.96; H, 3.22; N, 8.62. CCDC: 1404800.

Synthesis of $\left[\mathrm{Ag}(\mathrm{NPBA})_{2}\right]\left(\mathrm{PF}_{6}\right)(4)$. A solution of NPBA $(40 \mathrm{mg}, 0.20 \mathrm{mmol})$ in $10 \mathrm{~mL}$ of propanol was added to a separate solution containing silver hexafluorophosphate $(25.5 \mathrm{mg}, 0.10 \mathrm{mmol})$ in $10 \mathrm{~mL}$ of propanol. Upon mixing, the mixture did not immediately produce a precipitate, even after being allowed to react for several hours. The complex could be crystallized by allowing the propanol to evaporate slowly. Yield: $53.7 \mathrm{mg}$, 82\%; IR (cm $\left.\mathrm{cm}^{-1}\right)$ : 2359, 1662, 1589, 1520, 1417, 1334, 1218, 822, 706. Elemental analysis calculated for $\left[\mathrm{Ag}(\mathrm{NPBA})_{2}\right]\left(\mathrm{PF}_{6}\right): \mathrm{C}, 44.40 ; \mathrm{H}, 3.10 ; \mathrm{N}, 8.63$. Found: C, 46.27; H, 3.74; N, 8.46. CCDC: 1404801.

Synthesis of $\left[\mathrm{Ag}(\mathrm{NPBA})_{2}\right]\left(\mathrm{BF}_{4}\right)(5)$. A solution of NPBA $(40 \mathrm{mg}, 0.20 \mathrm{mmol})$ in $10 \mathrm{~mL}$ of methanol was added to a separate solution containing silver tetrafluoroborate $(19.6 \mathrm{mg}, 0.10 \mathrm{mmol}) \mathrm{in} 10 \mathrm{~mL}$ of methanol. After allowing the mixture to react for approximately $2 \mathrm{~h}$, a white precipitate appeared and was subsequently filtered. A saturated solution of this complex in DMF was prepared and left for diethyl ether diffusion over $48 \mathrm{~h}$ in the dark to obtain crystals, which were subsequently filtered and washed with diethyl ether. Yield: $51.3 \mathrm{mg}, 86 \%$; IR ( $\left.\mathrm{cm}^{-1}\right): 1658,1586,1517,1419,1334,1215,1011$, $822,705,589$. Elemental analysis calculated for $\left[\mathrm{Ag}(\mathrm{NPBA})_{2}\right]\left(\mathrm{BF}_{4}\right): \mathrm{C}, 48.77 ; \mathrm{H}, 3.41 ; \mathrm{N}, 9.48$. Found: C, 48.84; H, 3.49; N, 9.48. CCDC: 1404802.

Synthesis of $\left[\mathrm{Ag}(\mathrm{NPBA})_{2}\right]$ (tosylate) (6). A solution of NPBA $(20 \mathrm{mg}, 0.10 \mathrm{mmol})$ in $7 \mathrm{~mL}$ of ethanol was added to a separate solution containing silver tosylate $(14.4 \mathrm{mg}, 0.05 \mathrm{mmol})$ in $3 \mathrm{~mL}$ of ethanol. After allowing the mixture to react for $3 \mathrm{~h}$, a white precipitate formed and it was filtered from the reaction mixture. A saturated solution of this precipitate in methanol was left for diethyl ether diffusion for $48 \mathrm{~h}$ in the dark, and this generated colorless prism-shaped crystals. Yield: $28.9 \mathrm{mg}, 84 \%$; IR ( $\left.\mathrm{cm}^{-1}\right)$ : $1693,1601,1510,1165,1011,814,685,561$. Elemental analysis calculated for $\left[\mathrm{Ag}(\mathrm{NPBA})_{2}\right]($ tosylate): C, 55.12; H, 4.03; N, 8.29. Found: C, 55.00; H, 4.16; N, 8.30. CCDC: 1532773.

Synthesis of $\left[\mathrm{Ag}(\mathrm{NPBA})_{2}\right]$ (Phenyl sulfonate) (7). A mixture of sodium benzene-1,3-disulfonate (141 mg, $0.50 \mathrm{mmol})$ and silver nitrate $(170 \mathrm{mg}, 1.0 \mathrm{mmol})$ in $2 \mathrm{~mL}$ of water was stirred for $5 \mathrm{~min}$. Meanwhile, a solution of NPBA (190 mg, $1 \mathrm{mmol}$ ) was dissolved in $5 \mathrm{~mL}$ of methanol. After adding both solutions, there was immediate production of a white precipitate, which was dissolved by the dropwise addition of aqueous $\mathrm{NH}_{3}(2 \mathrm{~mL})$. The clear solution was kept for crystallization in the dark for one week, generating silver rectangular shaped crystals. Yield $132 \mathrm{mg}, 26.3 \%$; IR (cm $\left.{ }^{-1}\right): 2358,1674$, $1591,1504,1415,1327,1292,824,709$.

Characterization: Complexes 1-6 were characterized using a Nonius Kappa CCD diffractometer equipped with Mo K $\alpha$ radiation $(\lambda=0.71073 \AA$ ). Hydrogen atoms were located and refined isotropically using SHELXL-2018. XRPD (X-ray powder diffraction) measurements were performed on a D8 diffractometer from Bruker instruments (Billerica, MA, USA) $(\mathrm{Cu} \mathrm{K} \alpha$ radiation, $\lambda=0.154 \mathrm{~nm}$ ) with a scan rate of 2 degrees/min. The IR spectra were recorded using a Bruker Tensor 27 FT/IR (Billerica, MA, USA) in the range of $4000-500 \mathrm{~cm}^{-1}$. Differential scanning calorimetry (DSC) analysis was performed in a Q2000 DSC (New Castle, DE, USA). The OM (Optical Microscopy) analysis was conducted using an Olympus IX71 optical microscope (Center Valley, PA, USA). AFM (atomic force microscopy) analysis was conducted in a Dimension FastScan AFM (Billerica, MA, USA).

\section{Results and Discussion}

Synthesis. The syntheses of the Ag complexes 1-7 consisted of dissolving NPBA and the corresponding silver salt into methanol or ethanol, and allowing crystallization using diethyl ether diffusion in the dark. The crystals were isolated by filtration, and they were characterized with FTIR (Fourier-transform infrared spectroscopy), XRPD (X-ray powder diffraction), and X-ray crystallography.

Structure. Silver(I) bis-N-(4-pyridyl) benzamide has two molecules of NPBA coordinated to Ag(I) ion in the trans configuration (Figure 1). The carboxamide and phenyl groups in the complex allow it 
to form intermolecular donor/acceptor hydrogen bonds and $\pi-\pi$ stacking interactions, respectively. The single positive charge of the complex allowed for the study of the influence that various anions have on the arrangement of intermolecular hydrogen bonding and $\pi-\pi$ stacking interactions in the crystalline solid state. For this study, the anions selected were $\mathrm{NO}_{3}{ }^{-}$(1), $\mathrm{ClO}_{4}^{-}{ }^{-}$(2), $\mathrm{CF}_{3} \mathrm{SO}_{3}{ }^{-}$(3), $\mathrm{PF}_{6}{ }^{-}$(4), $\mathrm{BF}_{4}{ }^{-}(5), \mathrm{CH}_{3} \mathrm{PhSO}_{3}{ }^{-}(6)$, and $\mathrm{PhSO}_{3}{ }^{-}$(7). These counterions provided a variation in the charge density and electrostatic potential, as well as varying in their abilities to hydrogen bond and engage in $\pi-\pi$ stacking interactions.

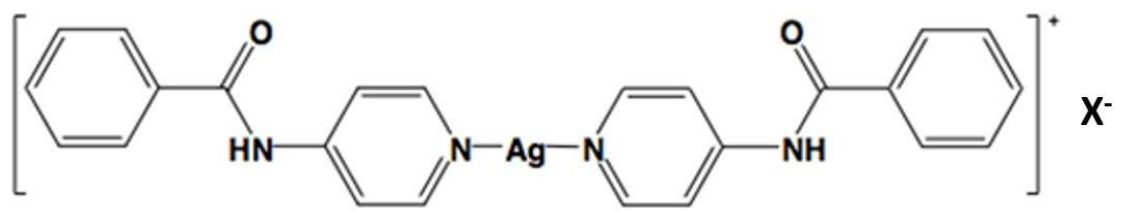

Figure 1. Structure of $\left[\mathrm{Ag}(\mathrm{NPBA})_{2}\right] \mathrm{X}$, where $\mathrm{X}^{-}=\mathrm{NO}_{3}{ }^{-}(1), \mathrm{ClO}_{4}^{-}{ }^{-}(2), \mathrm{CF}_{3} \mathrm{SO}_{3}{ }^{-}(3), \mathrm{PF}_{6}{ }^{-}$(4), $\mathrm{BF}_{4}^{-}$ (5), $\mathrm{CH}_{3} \mathrm{PhSO}_{3}{ }^{-}$(6), and $\mathrm{PhSO}_{3}{ }^{-}$(7).

The ORTEP (The Oak Ridge Thermal Ellipsoid Plot) view of Ag-complex $\mathbf{1}$ is shown in Figure 2a. It crystallizes in the triclinic crystal system in the Pì space group. The structure revealed the overall length of the ligand-Ag-ligand component, as defined by the internuclear distance from the furthest two hydrogens possible, to be $24.53 \AA$, and these two hydrogens formed a $166.2^{\circ}$ angle with the silver center. The $\mathrm{N}-\mathrm{Ag}-\mathrm{N}$ bond angle is $168.6^{\circ}$ and the planes formed by the pyridyl groups of the respective nitrogen atoms are offset by $5.0^{\circ}$. The two peripheral aromatic groups of the ligands form planes that intersect at an angle of $18.9^{\circ}$. Because the inner two pyridyl groups coordinated to the silver center are nearly coplanar, an average plane of the two can be created to be used as a reference for the outer aromatic portions of the ligand. The two outer phenyl planes of the ligands intersect this average plane at angles of $30.5^{\circ}$ and $46.3^{\circ}$ in the same direction. The bond lengths between the silver and the nitrogen atoms are $2.15 \AA$, whereas the distance between the silver and the oxygen belonging to the nitrate anion is $2.71 \AA$. The crystallographic values for compounds $\mathbf{2}-\mathbf{6}$ are shown in Table 1 .
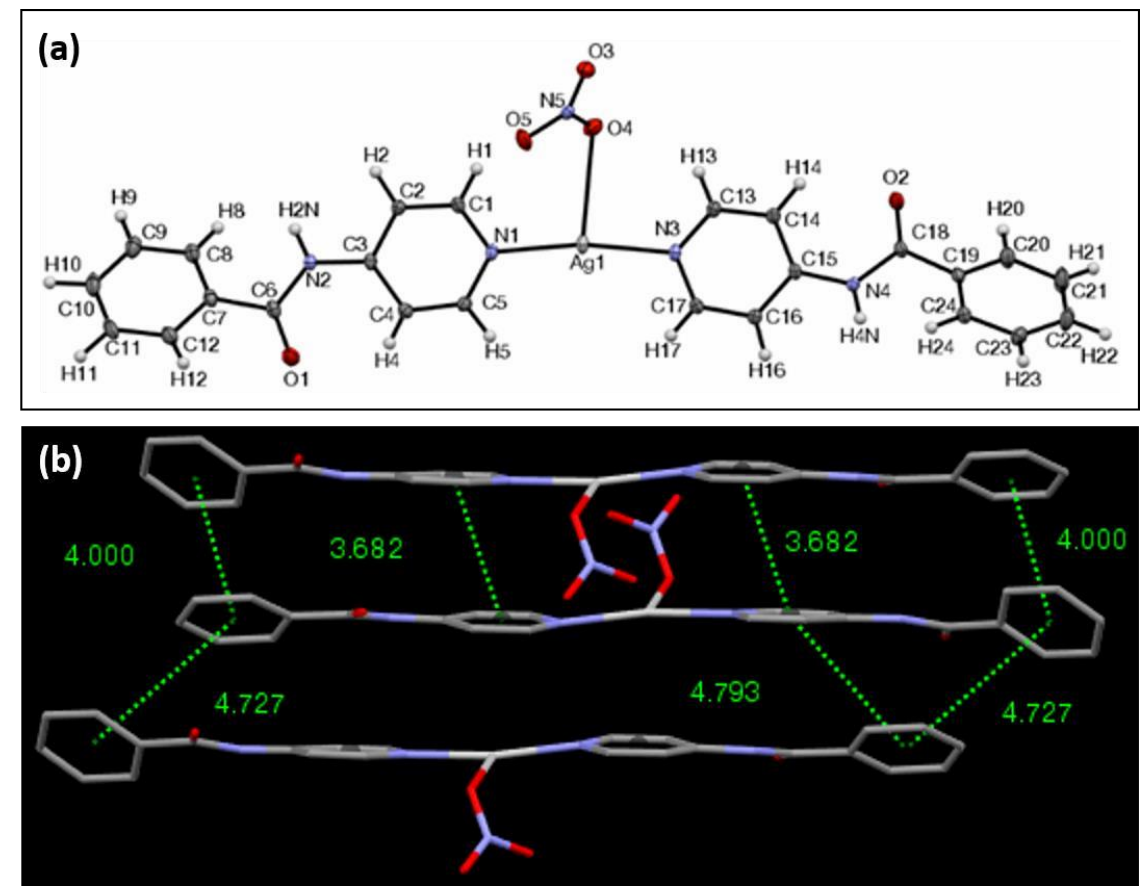

Figure 2. (a) ORTEP view of complex 1 with ellipsoids drawn at $30 \%$ probability; (b) View of the $\pi-\pi$ interaction network of complex $\mathbf{1}$, showing that the aromatic centroid-to-centroid distances are less than $4.80 \AA$. 
In Ag complex 1, the hydrogen bonding observed between the amide proton and the oxygen atom belonging to the nitrate anion are only separated by $2.11 \AA$. The amide oxygen also interacts with two nearby aromatic protons, with distances within $2.59 \AA$ and $2.49 \AA$. The distance between the silvers on two adjacent molecules within the lattice is $3.48 \AA$. A remarkable feature of Ag-complex 1 is the directional $\pi-\pi$ stacking interaction network that it exhibits (Figure $2 b$ ). The molecules stack lengthwise along the $a$ crystallographic axis on top of each other, allowing for a virtually complete overlap between the corresponding aromatic elements. The average planes of adjacent complexes that participate in the $\pi-\pi$ stacking are parallel with each other, while the peripheral phenyl planes of two adjacent $\pi-\pi$ stacked complexes intersect at one end at an angle of $18.8^{\circ}$ and at $18.9^{\circ}$. The opposing phenyl planes of two separate complexes are in parallel for one set, and for the other set, it intersects at an angle of $0.2^{\circ}$. There are a total of eight $\pi$-stacking interactions with centroid-to-centroid distances of $4.80 \AA$ or less. The central complex's aromatic centroids overlap with the centroids of the complex below it, and it is offset from the aromatic rings above it. This motif is repeated in such a way as to form a "column" of complexes where there is a slight offset in overlap at every other complex molecule. XRPD analysis of $\mathbf{1}$ revealed a consistency of the crystalline structure throughout the material (Supplementary Information, Figure S1). FTIR showed carbonyl stretching at $1740\left(\mathrm{~cm}^{-1}\right)$, amide stretching at $1675\left(\mathrm{~cm}^{-1}\right)$ and a C-N double bond at $1504\left(\mathrm{~cm}^{-1}\right)$.

The ORTEP view of Ag complex 2 with $\mathrm{ClO}_{4}{ }^{-}$as the counterion is shown in Figure 3a. It crystallizes in the triclinic crystal system in the Pì space group. The unit cell in this case consists of two molecules of the silver complex, each with a slightly different dimensional specification. One of the moieties measures $24.60 \AA$, whereas the second measures $24.63 \AA$ in overall length, as previously defined, and they form angles of $176.5^{\circ}$ and $179.7^{\circ}$ with respect to the outermost aromatic protons, respectively. The $\mathrm{N}-\mathrm{Ag}-\mathrm{N}$ bond lengths of each of the silver complexes in the unit cell are $2.13 \AA$, $2.13 \AA$, and $2.12 \AA, 2.12 \AA$ for each complex. The N-Ag-N bond angles for each complex were found to be $172.3^{\circ}$ and $176.0^{\circ}$. The Ag centers of the complexes were not coordinated to the perchlorate anions, as was the case with the nitrate complex. The pyridyl groups directly bonded to the Ag center are similarly not coplanar, and their respective planes intersect at an angle of $6.0^{\circ}$ for the first moiety, and $8.8^{\circ}$ for the second. The peripheral aromatic groups, those belonging to the phenyl rings of the ligand, intersect at an angle of $9.5^{\circ}$ and $9.5^{\circ}$ for each of the two complexes.
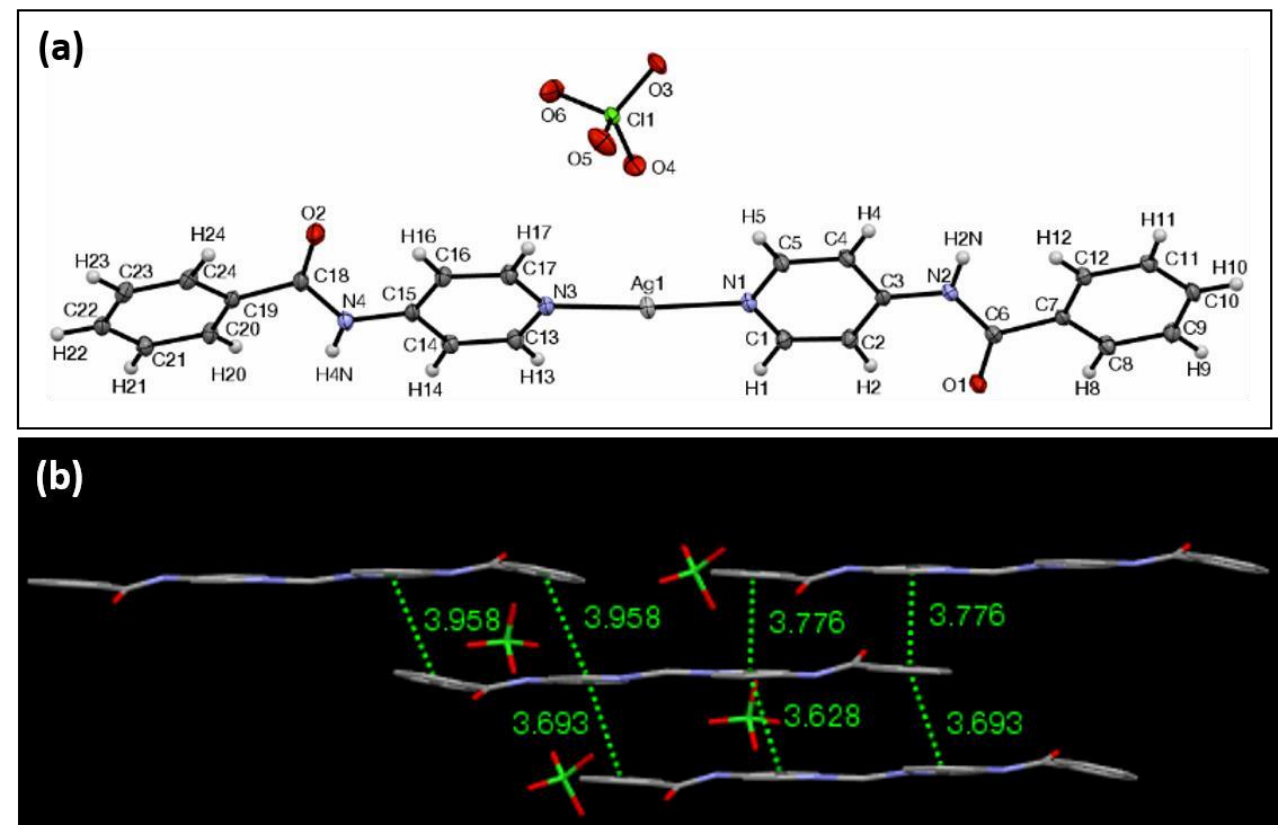

Figure 3. (a) ORTEP view of complex 2 with ellipsoids drawn at 30\% probability; (b) The view according to the inset of the intermolecular $\pi-\pi$ interactions of four adjacent molecules of complex 2 , highlighting the centroid-centroid distances that are less than $3.96 \AA$. 
Two types of hydrogen bonds are displayed within the structure of complex 2. One of them is between the amide proton and the oxygen of the perchlorate anion, which are separated by a distance of $2.17 \AA$. The other is between a solvent molecule of methanol, which was trapped within the lattice during the synthesis, and hydrogen bonds via its hydroxyl proton to the amide oxygen of the complex, with a distance of $1.98 \AA$. Complex 2 forms an extended $\pi-\pi$ stacking network along three dimensions in the crystal (Figure 3b). The distance between the nearest silver ions is $5.65 \AA$. While the silver ion centers are farther than those found in the other anion complexes, the $\pi-\pi$ stacking interactions are more pronounced, as one molecule of the complex can interact with as many as five other complexes. Four of the complexes are stacked in a lengthwise staggered arrangement, and they form a "sheet" with their average planes being essentially parallel, whereas the fifth complex lies slightly outside of this sheet and is diagonal to the central complex unit in a parallel displaced arrangement. Choosing any arbitrary complex molecule to analyze the $\pi$-interactions, there are seven centroid-to-centroid distances of less than $3.96 \AA$. An XRPD analysis of 2 revealed a consistency of crystalline structure throughout the material (Supplementary Information, Figure S2). FTIR analysis showed the carbonyl stretching at $1658\left(\mathrm{~cm}^{-1}\right)$.

The ORTEP view of complex 3 with $\mathrm{CF}_{3} \mathrm{SO}_{3}{ }^{-}$as the counterion is shown in Figure 4a. It crystallizes in the triclinic crystal system in the $\mathrm{P}_{\overline{1}}$ space group. The unit cell in this case consists of two molecules of the silver complex, as in the case of complex 2 . The first of the complexes measures at $24.63 \AA$, whereas the second measures at $24.48 \AA$ in overall length with respect to the first definition that was previously given, and both form perfectly linear angles of $180.0^{\circ}$ with respect to the outermost aromatic protons. The $\mathrm{N}-\mathrm{Ag}-\mathrm{N}$ bond lengths of each of the silver complexes in the unit cell are equivalent, unlike the previous complexes, and they measure 2.11 $\AA$ and $2.10 \AA$. The $\mathrm{N}-\mathrm{Ag}-\mathrm{N}$ bond angles for each were found to be equivalent for each moiety, and they are also perfectly linear at $180.0^{\circ}$. The Ag centers of the complexes are not coordinated to the triflouromethanesulfonate (triflate) anions. The pyridyl groups that are directly bonded to the Ag center are the closest to being coplanar in comparison with the other complexes, with their angles of intersection measuring $0.1^{\circ}$ and $0.5^{\circ}$. The planes of the phenyl rings of the ligands intersect at angles of $0.8^{\circ}$ and $0.1^{\circ}$ for each of the two complexes. The average planes of the complexes intersect at an angle of $85.3^{\circ}$.
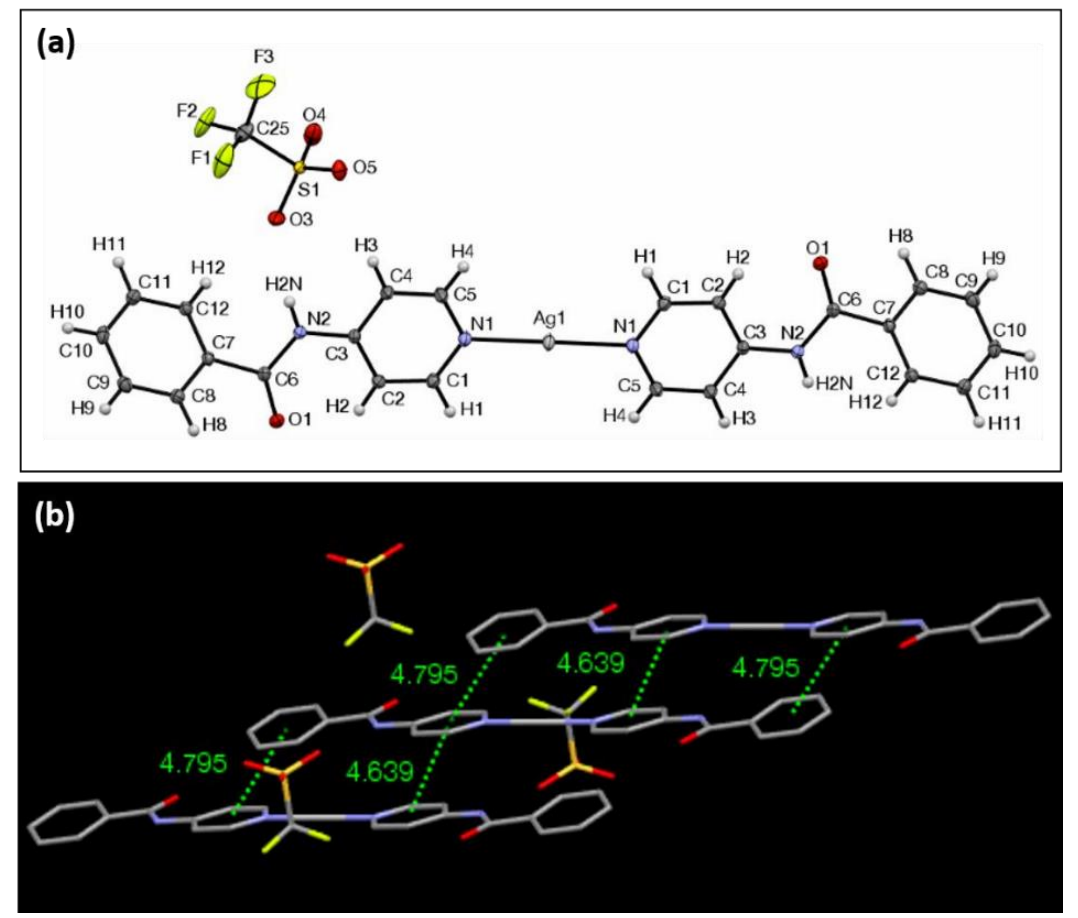

Figure 4. (a) ORTEP view of complex 3 with ellipsoids drawn at $30 \%$ probability. (b) The view of $\pi-\pi$ interactions of three adjacent molecules of complex 3 , showing centroid-to-centroid distances of less than $4.80 \AA$. 
Hydrogen bonding is present within the lattice between adjacent oxygen atoms of the triflouromethanesulfonate anion and the amide proton of two adjacent complexes, and these have a distance of $2.13 \AA$, and $2.27 \AA$. The two complex molecules that participate in these interactions do not belong to the same unit cell, but their average planes also intersect at an angle of $85.3^{\circ}$. The closest silver-to-silver spacing is $7.47 \AA$. The overall structure of the lattice exhibits alternating layers of the complexes, arranged in a type of three-dimensional herringbone array (Figure 4b). Again, choosing any arbitrary complex molecule for $\pi$-interaction analysis shows that there are five $\pi-\pi$ interactions with centroid-to-centroid distances of less than $4.80 \AA$. An XRPD analysis of 3 revealed that other polymorphs may be present throughout the material (Supplementary Information, Figure S3). FTIR analysis showed carbonyl stretching at $1682\left(\mathrm{~cm}^{-1}\right)$.

The ORTEP view of complex 4 with $\mathrm{PF}_{6}{ }^{-}$as the counterion is shown in Figure 5a. It crystallizes in the triclinic crystal system in the Pī space group. The overall length of the ligand-Ag-ligand component is $24.57 \AA$, and the two outermost hydrogens form a $175.6^{\circ}$ angle with the silver center. The $\mathrm{N}-\mathrm{Ag}-\mathrm{N}$ bond angle is $175.8^{\circ}$, and the planes formed by the pyridyl groups of the respective nitrogen atoms intersect at an angle of $5.0^{\circ}$. The two peripheral aromatic groups of the ligands form planes that intersect at an angle of $13.6^{\circ}$. The two outer phenyl planes of the ligands intersect the average plane of the inner pyridyl planes at angles of $20.7^{\circ}$ and $8.0^{\circ}$. The bond lengths between the silver and the nitrogen are $2.13 \AA$ and $2.14 \AA$. As is typical of these complexes, $\pi-\pi$ stacking interactions predominate, as any one individual complex can form strong interactions with as many as three other complexes (Figure 5b). Unlike the case of complex 2, the average planes of adjacent complexes that participate in the $\pi-\pi$ stacking are not in parallel with each other. There are seven $\pi-\pi$ interactions with centroid distances of $4.54 \AA$ or less. XRPD analysis of 4 revealed that other polymorphs may be present throughout the material (Supplementary Information, Figure S4). FTIR analysis shows the carbonyl stretching at $1662\left(\mathrm{~cm}^{-1}\right)$.
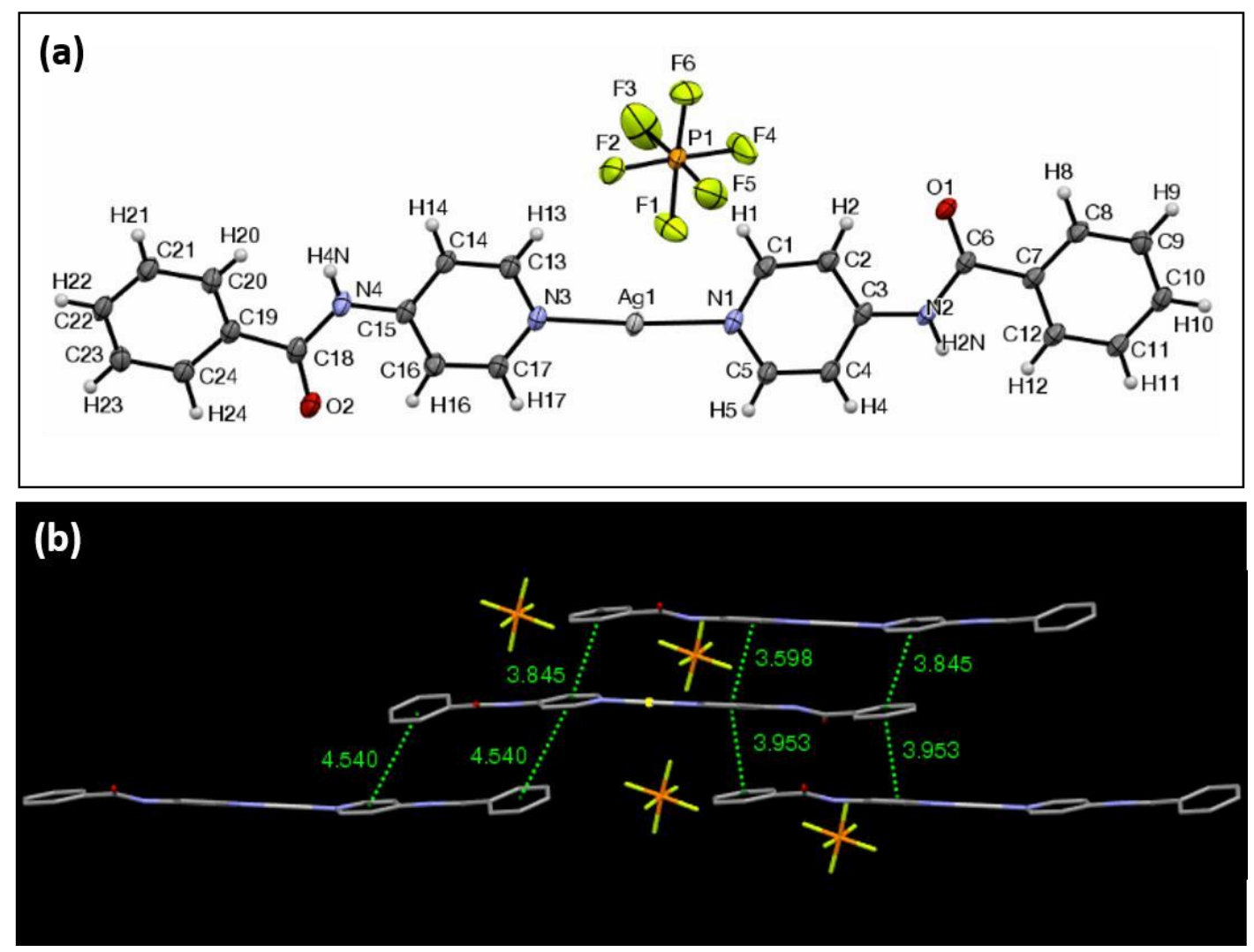

Figure 5. (a) The ORTEP view of complex 4 with ellipsoids drawn at $30 \%$ probability. (b) The view of the $\pi-\pi$ interaction network of complex 4, highlighting centroid-centroid distances of less than $4.54 \AA$. 
The ORTEP view of complex 5 with BF4- as the counterion is shown in Figure 6a. It crystallizes in the triclinic crystal system in the Pì space group. The unit cell in this case consists of the anion, two molecules of the silver complex, and two molecules of methanol, the solvent used for crystallization. The two complex molecules and methanol molecules are symmetrical with respect to an inversion center between them, with the methanol molecules being disordered over their positions. The length of the complex, as previously defined in all structures, is $24.68 \AA$. The two $\mathrm{N}-\mathrm{Ag}$ bond lengths are 2.12 and $2.12 \AA$. The $\mathrm{N}-\mathrm{Ag}-\mathrm{N}$ bond angle is $178.1^{\circ}$. The methanolic oxygen is coordinated to silver, with a distance of $2.67 \AA$. The pyridyl groups directly bonded to the Ag center are not coplanar, with their respective planes intersecting at an angle of $17.0^{\circ}$. The peripheral aromatic groups, those belonging to the phenyl rings of the ligand, intersect at an angle of $18.7^{\circ}$. Complex 5 forms an extended $\pi-\pi$ stacking network along two dimensions in the crystal, and a single complex molecule forms $\pi-\pi$ stacking interactions with three molecules in the immediate vicinity (Figure 6b). Three of those interactions are face-to-face interactions between the complexes, which helps to form a sheet-like array of complexes that are arranged in a brick-like pattern. There are seven aromatic centroid-to-centroid distances of $4.00 \AA$ or less. XRPD analysis of 5 revealed that other polymorphs may be present throughout the material (Supplementary Information, Figure S5). The FTIR shows the carbonyl stretching at $1658\left(\mathrm{~cm}^{-1}\right)$.
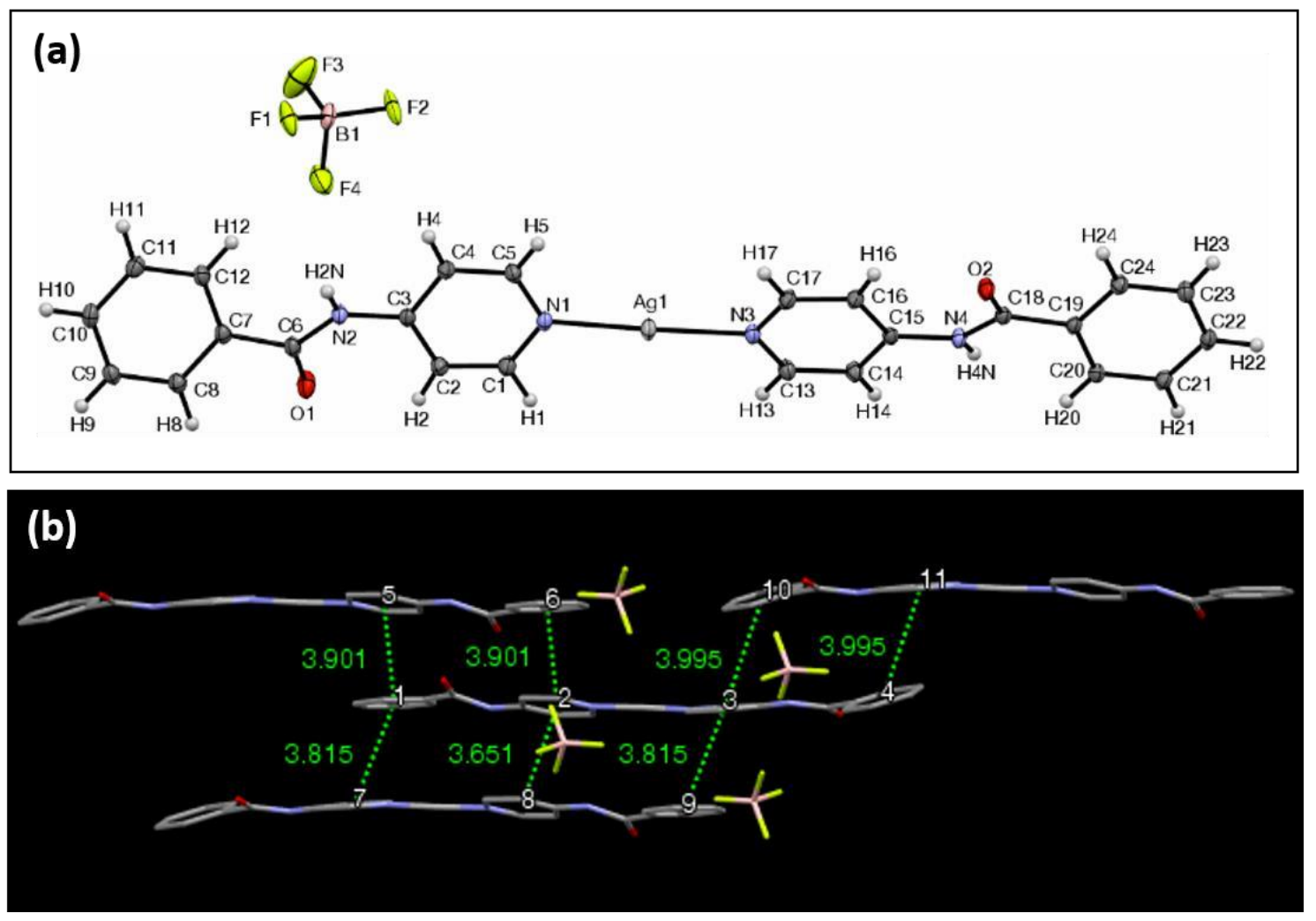

Figure 6. (a) The ORTEP view of complex 5, with ellipsoids drawn at $30 \%$ probability. (b) The view of the $\pi-\pi$ interaction network of complex 5 , highlighting the centroid-centroid distances of less than $4.00 \AA$.

The ORTEP view of complex 6 with $\mathrm{CH}_{3} \mathrm{C}_{6} \mathrm{H}_{4} \mathrm{SO}_{3}{ }^{-}$as the counterion is shown in Figure 7a. It crystallizes in the triclinic crystal system in the $\mathrm{P} \overline{1}$ space group. In this complex, the $\mathrm{N}-\mathrm{Ag}-\mathrm{N}$ bond lengths are $2.12 \AA$ and $2.12 \AA$, with the overall length of the complex being $24.54 \AA$. The N-Ag-N angle was measured to be $176.9^{\circ}$, and the distance between an oxygen atom of the p-toluenesulfonate (tosylate) anion to the silver center was $2.90 \AA$. Once again, as typical in these complexes, the planes formed by the pyridyl groups are not coplanar, and they intersect at an angle of $6.9^{\circ}$. The peripheral 
planes formed by the exterior phenyl rings intersect at an angle of $13.9^{\circ}$. The angles formed by the phenyl groups and the average plane of the pyridyl groups are $26.9^{\circ}$ and $13.1^{\circ}$, with both exterior groups rotating in the same direction relative to the inner plane.

Hydrogen bonds are displayed between the amide protons and the p-toluenesulfonate oxygens, whose internuclear distance is $2.01 \AA$. The shortest distance between any two silver centers is $3.74 \AA$. Complex 6 is unique in the sense that the p-toluenesulfonate anion itself contains an aromatic $\pi$ system that also participates within the $\pi-\pi$ stacking network between the ligand-Ag-ligand portions of the complex (Figure $7 \mathrm{~b}$ ). One complex molecule interacts with two other complexes and two of the p-toluenesulfonate anions. There are six $\pi$-interactions with adjacent complexes and two $\pi$-interactions with the tosylate anion, all of which are $4.25 \AA$ or less. XRPD analysis of 6 revealed that other polymorphs may be present throughout the material (Supplementary Information, Figure S6). The FTIR, shows the carbonyl stretching at $1693\left(\mathrm{~cm}^{-1}\right)$.
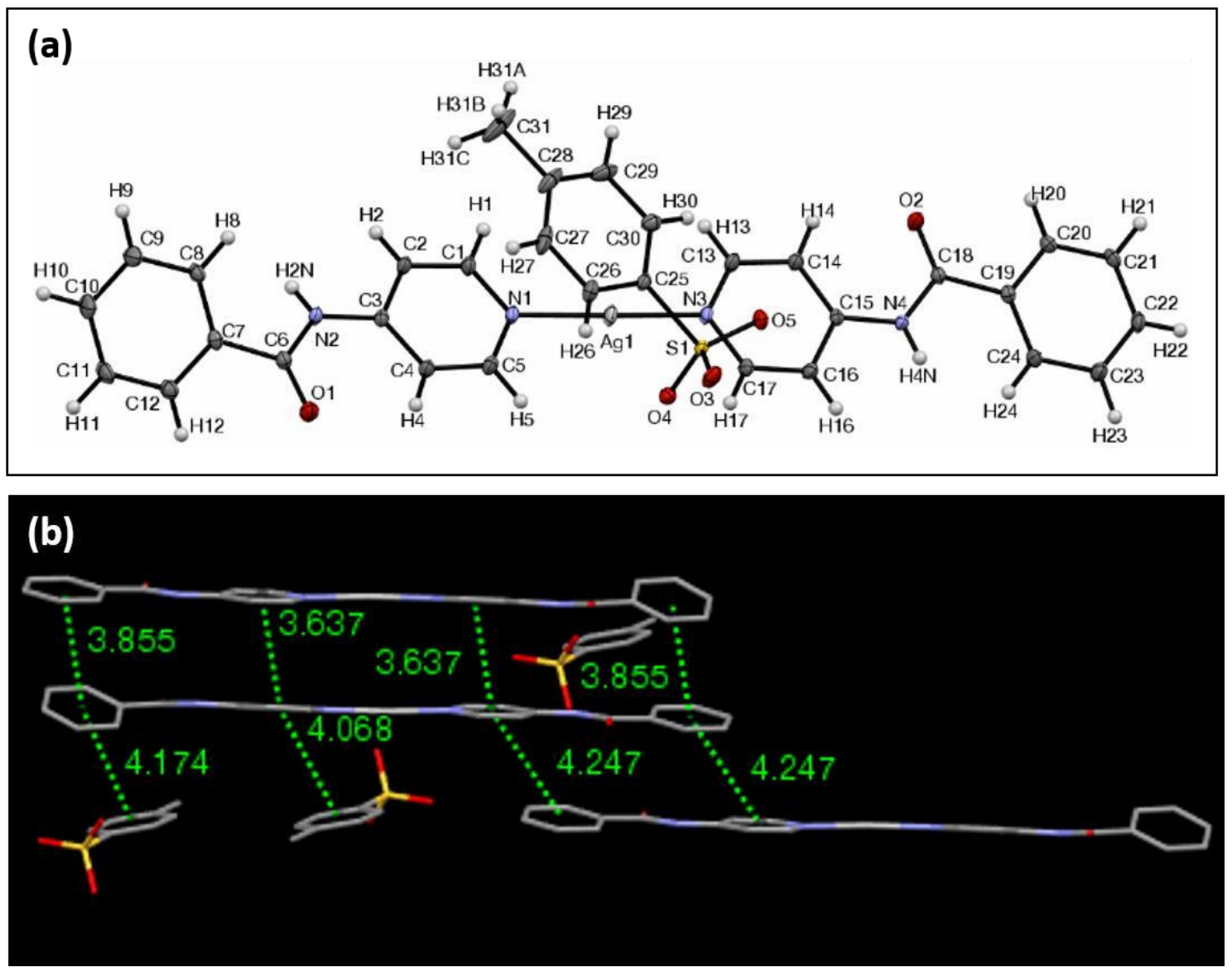

Figure 7. (a) The ORTEP view of complex 6, with ellipsoids drawn at $30 \%$ probability. (b) The view according to $\pi-\pi$ interaction network complex 6 , highlighting the centroid-to-centroid distances of $4.25 \AA$ or less.

Mesomorphic Phase. Ag complexes $\mathbf{6}$ and $\mathbf{7}$ formed mesomorphic phases when the DMF solutions of the complexes were heated to $130 \mathrm{oC}$ and allowed to slowly evaporate (Figure 8 and Supplementary Information, Figure S7). The mesomorphic phases consist of flexible fibers, presumably of $\pi-\pi$ stacking networks, that range in size from the nanometer to the micron scale. When the Ag complexes 1-5, which do not have $\pi-\pi$ stacking counterions, were placed under similar conditions, they formed ordinary microcrystalline materials (Supplementary Information, Figure S7). Since the Ag complexes 6 and 7 have counterions that are capable of $\pi-\pi$ stacking via the phenyl moiety, it is likely that at high temperature in DMF, they cause bifurcation of the crystal lattice, resulting in flexible $\pi-\pi$-driven fibers and the mesomorphic phases. To our knowledge, this is the first example of this type of phenomena, 
which opens a wide range of possibilities to develop novel stacking organic materials with unique properties, and potential applications in the design of novel high-surface area organic semiconductors.

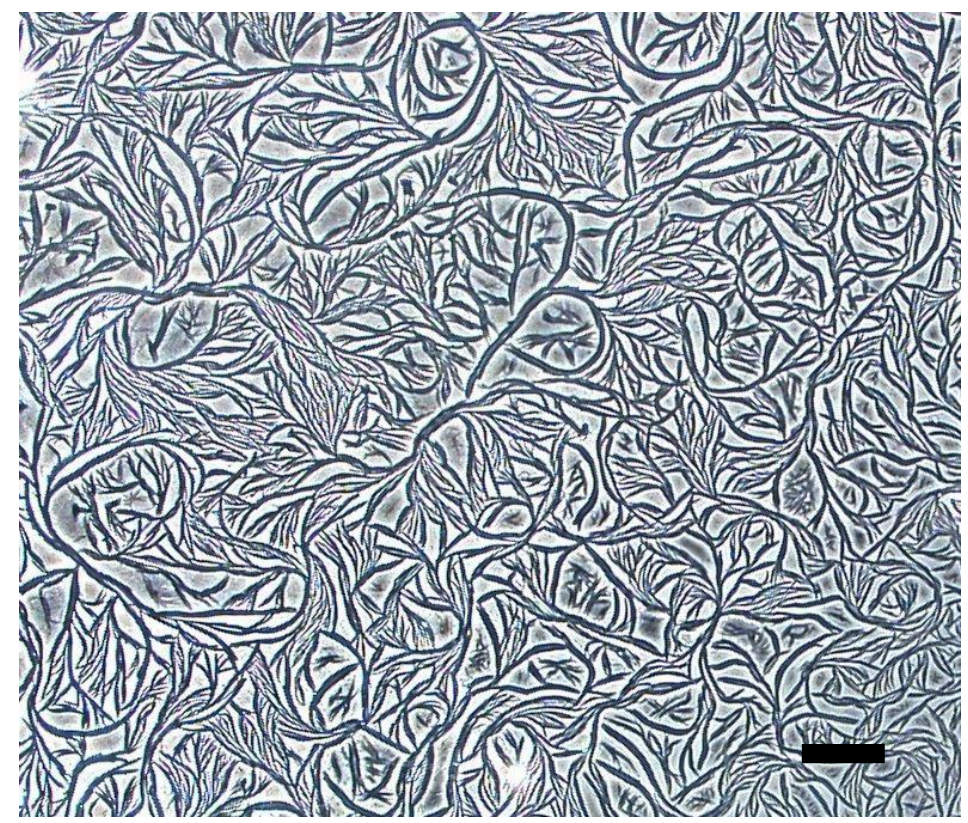

Figure 8. Optical microscopy images of mesomorphic phases of 6 in dimethylformamide (DMF). Scale bar is $50 \mu \mathrm{m}$.

Atomic Force Microscopy. Figure 9 shows the atomic force microscopy scan of the mesomorphic phase of complex 6 during its nucleation and crystal growth from DMF after heating at $130{ }^{\circ} \mathrm{C}$. AFM indicated that the nanocrystals of complex 6 bifurcate into branches as small as $30 \mathrm{~nm}$ that eventually interconnect, forming long range networks that result in mesoscale phases.
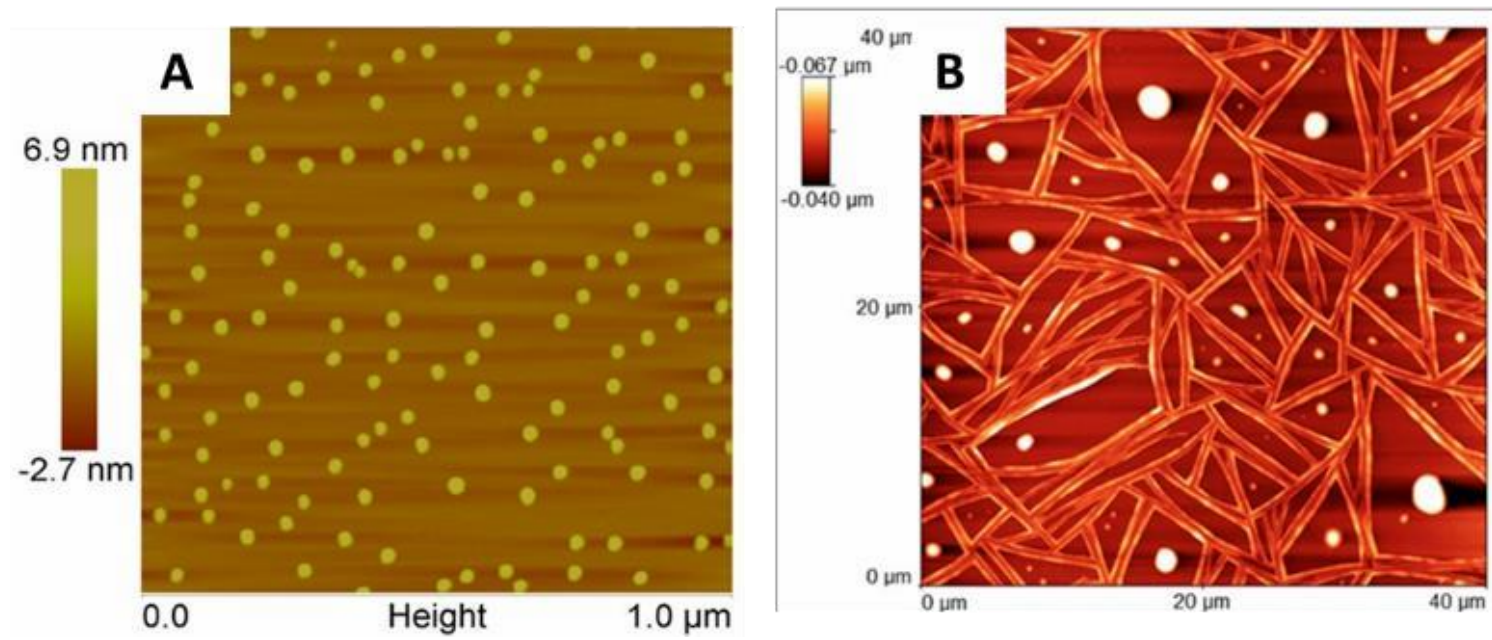

Figure 9. Atomic force microscopy (AFM) of crystal 6 during (A) nucleation and (B) growth in DMF at $130{ }^{\circ} \mathrm{C}$.

Differential Scanning Calorimetry. In order to investigate whether there were any special physical properties that contributed to the mesomorphic crystals, we studied crystals 1-6 with DSC. Figure 10 shows the heating thermographs of crystals 1-6 heated from room temperature to $200{ }^{\circ} \mathrm{C}$. The results indicated strong endothermic points associated with melting points for crystals 2, 3, 4, and 6 at 119, 76,125 , and $92{ }^{\circ} \mathrm{C}$, respectively. Only crystal 5 appeared to decompose at over $150{ }^{\circ} \mathrm{C}$. These results indicate that there is no remarkable thermal behavior in the $\mathrm{Ag}$ complexes in the solid state, and that 
the mesomorphic phases are most likely related to the mechanisms of crystal growth during the interference of $\pi-\pi$ stackable counterions in solution at high temperatures.

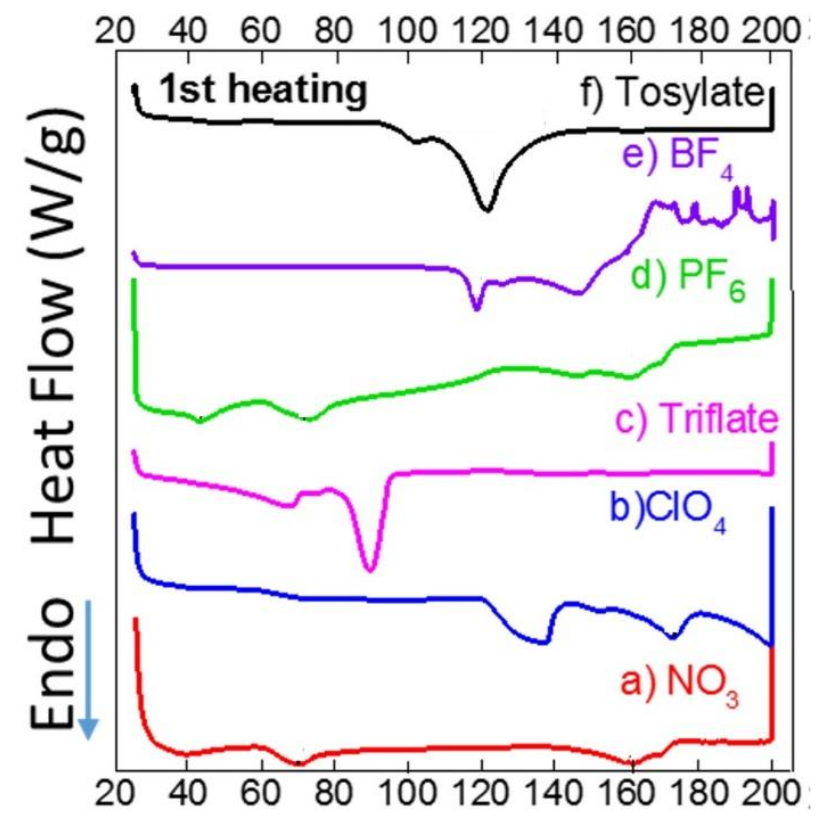

Figure 10. Thermographs for crystals 1-6 when heated from room temperature to $200{ }^{\circ} \mathrm{C}$.

DFT (Density Functional Theory) calculation of band gaps. Since polycyclic aromatic hydrocarbon with $\pi-\pi$ stacking interactions in the solid-state are known to exhibit semi-conducting properties due to their low band gap properties, we carried an all-electron calculation using DFT in NRLMOL [59-64] to determine the theoretical band gaps of 1-6. This was accomplished using the crystal structures of the compounds, and employing a large polarized Gaussian basis set for the calculations. The Perdew-Burke-Ernzerhof exchange-correlation functional was applied. The band gaps, as given by DFT using the pure functionals, were underestimated; therefore, the quasi particle (QP) gap was calculated using a finite model from the difference between the ionization potential and electron affinity of the finite system. The ionization energy, from the delta-SCF (Self-consistent Field) method, was well-defined within DFT, since both energies of both the neutral and charged systems were obtained as ground state energies. The QP gaps are typically larger than the optical gaps since the excitation binding energies are not taken into account; thus, they form an upper bound to the band gap of the materials under study. The molecular model consisted of clusters of two to four units of Ag complexes with the interstitial linking units. We noted that the crystal field effect was pronounced in these systems, with smaller ionization energies for the larger clusters. The necessity to consider larger clusters limited our ability to calculate the optical spectra using TDDFT (Time-dependent density functional theory). The simulated band gaps are shown in Table 2 . The calculated band gap energies for complexes 1-6 based on their crystal structure were 3.25, 3.68, 1.48, 5.08, 1.53, and $3.55 \mathrm{eV}$, respectively. Experimental measurements of the band gaps of the Ag complexes were difficult to obtain, due to the polymorphic nature of the crystals. However, we were able to measure the experimental band gap using solid-state UV absorption spectra for the mono-morphic Ag complexes 1-3, and the resulting band gaps were determined to be $3.85,3.90$, and $3.89 \mathrm{eV}$, respectively. The calculations were generally close to the experimental values in the monomorphic crystals. Interestingly, the theory predicted very low band gap energies for crystals 3 and 5. Investigating the semi-conductive properties of the Ag complexes will be the subject of future reports. 
Table 1. Crystallographic data for Ag complexes 2-6.

\begin{tabular}{|c|c|c|c|c|c|}
\hline Ag Complex & 2 & 3 & 4 & 5 & 6 \\
\hline FW (Formula Weight) & 619.78 & 653.38 & 679.33 & 614.15 & 675.5 \\
\hline Crystal syst. & Triclinic & Triclinic & Triclinic & Triclinic & Triclinic \\
\hline Space Group & $P_{\overline{1}}$ & $P_{\overline{1}}$ & $P_{\overline{1}}$ & $P_{\overline{1}}$ & $\mathrm{P}_{\overline{1}}$ \\
\hline a $(\AA)$ & $9.8275(2)$ & $7.46740(1)$ & 9.9001(7) & $9.8917(2)$ & $10.7933(2)$ \\
\hline $\mathrm{b}(\AA)$ & $12.4752(2)$ & $10.0328(2)$ & $10.7078(7)$ & $10.5460(2)$ & $10.8375(2)$ \\
\hline$c(\AA)$ & $21.0802(3)$ & $17.8647(5)$ & 13.0099(10) & $12.3966(3)$ & $14.0935(3)$ \\
\hline$\alpha$ (degrees) & 73.7175(11) & $84.7974(8)$ & $77.930(3)$ & $74.8291(10)$ & $67.7623(7)$ \\
\hline$\beta$ (degrees) & $79.3526(10)$ & $85.6311(8)$ & $75.843(4)$ & $74.8542(9)$ & $76.8080(7)$ \\
\hline ty (degrees) & $76.1280(7)$ & $72.2666(16)$ & $81.012(5)$ & $80.3443(8)$ & $66.1412(12)$ \\
\hline $\mathrm{V}(\AA \circ 3)$ & $2389.18(7)$ & $1267.89(5)$ & 1299.65(16) & $1197.89(4)$ & $1390.03(5)$ \\
\hline Z (Formula units) & 4 & 2 & 2 & 2 & 2 \\
\hline $\mathrm{D}_{\text {calcd }}\left(\mathrm{Mg} / \mathrm{m}^{3}\right)$ & 1.732 & 1.711 & 1.736 & 1.703 & 1.614 \\
\hline$\mu\left(\mathrm{mm}^{-1}\right)$ & 1.008 & 0.944 & 0.915 & 0.907 & 0.85 \\
\hline Data/restrains/parameters & $10,777 / 0 / 860$ & $5640 / 0 / 435$ & $5428 / 0 / 452$ & $5325 / 0 / 438$ & $6163 / 0 / 476$ \\
\hline GOF (Goodness of fit) & 1.013 & 1.052 & 1.063 & 1.038 & 1.055 \\
\hline Final $R$ indices $(1>2 \sigma(1))$ & $\begin{array}{c}R 1=0.0363 \\
w R 2=0.0843\end{array}$ & $\begin{array}{c}R 1=0.0290 \\
w R 2=0.0688\end{array}$ & $\begin{array}{c}R 1=0.0556 \\
w R 2=0.1370\end{array}$ & $\begin{array}{c}R 1=0.0334 \\
w R 2=0.0835\end{array}$ & $\begin{array}{c}\mathrm{R} 1=0.0265 \\
\mathrm{wR} 2=0.0634\end{array}$ \\
\hline Final R indices (all data) & $\begin{array}{l}\mathrm{R} 1=0.0565 \\
\mathrm{wR} 2=0.0960\end{array}$ & $\begin{array}{c}R 1=0.0350 \\
w R 2=0.0725\end{array}$ & $\begin{array}{c}\mathrm{R} 1=0.0744 \\
\mathrm{w} 22=0.1538\end{array}$ & $\begin{array}{c}R 1=0.0376 \\
w R 2=0.0865\end{array}$ & $\begin{array}{c}\mathrm{R} 1=0.0319 \\
\mathrm{w} 22=0.0666\end{array}$ \\
\hline
\end{tabular}

Table 2. Experimental and calculated band gap energies (eV) of Ag complexes 1-6.

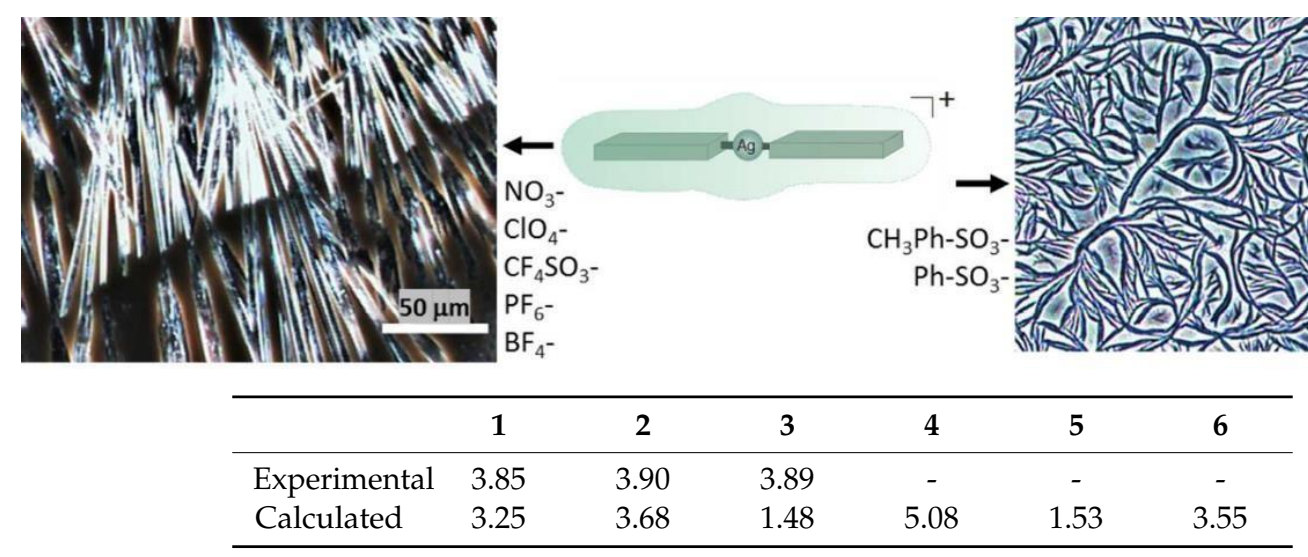

Mesomorphic fibers induced by $\pi-\pi$ stacking-capable anions in silver(I) $N$-(4-pyridyl)benzamide.

\section{Conclusions}

In summary, we have synthesized seven silver(I) $\mathrm{N}$-(4-pyridyl) benzamide complexes (1-7) with varying counter ions that form a rich array of $\pi-\pi$ stacking networks via the phenyl moiety in the ligand, which propagate in 1D, 2D and 3D crystal directions. This systematic study allowed us to discover that when the counterions are capable of $\pi-\pi$ stacking, as is the case for $\mathbf{6}$ and 7 , they can interfere during the crystal growth in DMF at $130{ }^{\circ} \mathrm{C}$, and induce the formation of highly branched, flexible fibers that extend from $\sim 30 \mathrm{~nm}$ in diameter to the micron scale, resulting in mesomorphic phases. DFT calculations of the band gaps of the Ag complexes predicted that the Ag complexes have generally low band gaps from 3.25-5.05, some of which were closely corroborated with experimental measurements. Taken together, the ability to induce nanoscale bifurcations in $\pi-\pi$ stacking rich 
materials that also exhibit low band gap properties can lead to a new generation of highly branched organic semiconductors for applications in molecular electronics.

Supplementary Materials: The following are available online at http:/ /www.mdpi.com/1996-1944/11/9/1666/ s1: CCDC data of crystals 2-6, XRD data, FTIR, optical microscopy, and crystallographic data are available in Supplementary Information.

Author Contributions: Conceptualization, J.C.N.; Software. T.B.; Formal Analysis, M.J.R. and H.E.; Investigation, M.R., I.T., H.P., N.D., J.G., T.-Q.N., A.M., Data Curation, A.A.; Writing-Original draft, I.T., N.D. and J.C.N.; Writing-Review \& Editing, M.R. and N.D.; Supervision, J.C.N.; Project Administration, M.R.; Funding Acquisition, J.C.N.

Funding: This research was funded by I-DISCOVER USDA Program HSI NIFA grant number 2014-38422-22078, the NSF EEC-1449500 Nanosystems Engineering Research Center on Nanotechnology-Enabled Water Treatment (NEWT), the NSF PREM DMR-1205302. Financial support by the Ralph \& Kathleen Ponce de Leon Endowment are gratefully acknowledged.

Acknowledgments: We are greatlful for the financial support from I-DISCOVER USDA Program HSI NIFA grant number 2014-38422-22078, the NSF EEC-1449500 Nanosystems Engineering Research Center on Nanotechnology-Enabled Water Treatment (NEWT), the NSF PREM DMR-1205302. Financial support by the Ralph \& Kathleen Ponce de Leon Endowment.

Conflicts of Interest: The authors declare no conflicts of interest.

\section{References}

1. Parker, S.; Vosguerichian, M.; Bao, Z. A review of fabrication and applications of carbon nanotube film-based flexible electronics. Nanoscale 2013, 5, 1727-1752. [CrossRef] [PubMed]

2. Murphy, R.; Frechet, J.M.J. Organic Semiconducting Oligomers for use in Thin Film Transistors. Chem. Rev. 2007, 107, 1066-1096. [CrossRef] [PubMed]

3. Katz, H.E. Recent Advances in Semiconductor Performance and Printing Processes for Organic TransistorBased Electronics. Chem. Mater. 2004, 16, 4748-4756. [CrossRef]

4. Kovac, J.; Peternai, L.; Lengyel, O. Advanced light emitting diodes structures for optoelectronic applications. Thin Solid Films 2003, 433, 22-26. [CrossRef]

5. Ho, P.K.H.; Kim, J.S.; Burroughes, J.H.; Becker, H.; Li, S.F.Y.; Brown, T.M.; Cacialli, F.; Friend, R.H. Molecular-scale interface engineering for polymer light-emitting diodes. Nature 2000, 404, 481-484. [CrossRef] [PubMed]

6. Burroughes, J.H.; Bradley, D.D.C.B.; Brown, A.R.; Marks, R.N.; Mackay, K.; Friend, R.H.; Burns, P.L.; Holmes, A.B. Light-emitting diodes based on conjugated polymers. Nature 1990, 347, 539-541. [CrossRef]

7. Coakley, K.M.; McGehee, M.D. Conjugated Polymer Photovoltaic Cells. Chem. Mater. 2004, 16, 4533-4542. [CrossRef]

8. Padinger, F.; Rittberger, R.S.; Sariciftci, N.S. Effects of Postproduction Treatment on Plastic Solar Cells. Adv. Funct. Mater. 2003, 13, 85-88. [CrossRef]

9. Brabec, C.J.; Sariciftci, N.S.; Hummelen, J.C. Plastic Solar Cells. Adv. Funct. Mater. 2001, 11, 15-26. [CrossRef]

10. Chakrabarty, R.; Mukherjee, P.S.; Stang, P.J. Supramolecular coordination: Self-assembly of finite two- and three-dimensional ensembles. Chem. Rev. 2011, 111, 6810-6918. [CrossRef] [PubMed]

11. Shevchenko, E.V.; Talapin, D.V.; Kotov, N.A.; O’Brien, S.; Murray, C.B. Structural diversity in binary nanoparticle superlattices. Nature 2006, 439, 55-59. [CrossRef] [PubMed]

12. Hecht, S. Optical switching of hierarchical self-assembly: Towards "enlightened" materials. Small 2005, 1, 26-29. [CrossRef] [PubMed]

13. Zhang, J.P.; Zhang, Y.B.; Lin, J.B.; Chen, X.M. Metal azolate frameworks: From crystal engineering to functional materials. Chem. Rev. 2012, 112, 1001-1033. [CrossRef] [PubMed]

14. Wasio, N.A.; Quardokus, R.C.; Forrest, R.P.; Lent, C.S.; Corcelli, S.A.; Christie, J.A.; Henderson, K.W.; Kandel, A.S. Self-assembly of hydrogen-bonded two-dimensional quasicrystals. Nature 2014, 507, 86-89. [CrossRef] [PubMed]

15. El Bakkali, H.; Castiñeiras, A.; García-Santos, I.; González-Pérez, J.M.; Niclós-Gutiérrez, J. MetalloSupramolecular Structures by Self-Assembly through Weak Interactions in Mixed Ligand Metal Complexes of Adenine and Malonate. Cryst. Growth Des. 2014, 14, 249-260. [CrossRef] 
16. Xiang, J.; Luo, Y.; Zhao, L.L.; Wang, C.H.; Wu, J.S. Ancillary ligands assisted self-assembly of metal organic frameworks: Synthesis, crystal structures and photophysical properties of two Zn(II) complexes containing in-situ formed tetrazole ligands. Inorg. Chem. Commun. 2013, 31, 23-28. [CrossRef]

17. Tiekink, E.R.; Zukerman-Schpector, J. The Importance of Pi-Interactions in Crystal Engineering: Frontiers in Crystal Engineering; Wiley-VCH: Chichester, UK, 2012.

18. Bushuyev, O.S.; Tomberg, A.; Vinden, J.R.; Moitessier, N.; Barrett, C.J.; Friščić, T. Azo phenyl stacking: A persistent self-assembly motif guides the assembly of fluorinated cis-azobenzenes into photo-mechanical needle crystals. Chem. Commun. 2016, 52, 2103-2106. [CrossRef] [PubMed]

19. Zhang, D.-W.; Zhao, X.; Hou, J.-L.; Li, Z.-T. Aromatic Amide Foldamers: Structures, Properties, and Functions. Chem. Rev. 2012, 112, 5271-5316. [CrossRef] [PubMed]

20. Briseno, A.L.; Mannsfeld, S.C.B.; Reese, C.; Hancock, J.M.; Xiong, Y.; Jenekhe, S.A.; Bao, Z.; Xia, Y. Perylenediimide nanowires and their use in fabricating field-effect transistors and complementary inverters. Nano Lett. 2007, 7, 2847-2853. [CrossRef] [PubMed]

21. Yip, H.L.; Zou, J.; Ma, H.; Tian, Y.; Tucker, N.M.; Jen, A.K.-Y. Patterning of robust self-assembled n-type hexaazatrinaphthylene-based nanorods and nanowires by microcontact printing. J. Am. Chem. Soc. 2006, 128, 13042-13043. [CrossRef] [PubMed]

22. Hill, D.J.; Mio, M.J.; Prince, R.B.; Hughes, T.S.; Moore, J.S. A field guide to foldamers. Chem. Rev. 2001, 101, 3893-4012. [CrossRef] [PubMed]

23. Chand, B.; Ray, U.; Mostafa, G.; Lu, T.H.; Sinha, C. 2D Extended supramolecular structures via $\pi-\pi$ interactions of 1D coordination polymers of cadmium(II) complexes of arylazoimidazole using azido and thiocyanato bridging ligands. Polyhedron 2004, 23, 1669-1676. [CrossRef]

24. Balakrishnan, K.; Datar, A.; Zhang, W.; Yang, X.; Naddo, T.; Huang, J.; Zuo, J.; Yen, M.; Moore, J.S.; Zang, L. Nanofibril self-assembly of an arylene ethynylene macrocycle. J. Am. Chem. Soc. 2006, 128, 6576-6577. [CrossRef] [PubMed]

25. Labastide, J.A.; Thompson, H.B.; Marques, S.R.; Colella, N.S.; Briseno, A.L.; Barnes, M.D. Directional charge separation in isolated organic semiconductor crystalline nanowires. Nat. Commun. 2016, 7, 10629. [CrossRef] [PubMed]

26. Paquin, F.; Latini, G.; Sakowicz, M.; Karsenti, P.-L.; Wang, L.; Beljonne, D.; Stingelin, N.; Silva, C. Charge separation in semicrystalline polymeric semiconductors by photoexcitation: Is the mechanism intrinsic or extrinsic? Phys. Rev. Lett. 2011, 106, 197401. [CrossRef] [PubMed]

27. Yamagata, H.; Spano, F.C. Interplay between intrachain and interchain interactions in semiconducting polymer assemblies: The HJ-aggregate model. J. Chem. Phys. 2012, 136, 184901. [CrossRef] [PubMed]

28. Scholes, G.D.; Rumbles, G. Excitons in nanoscale systems. Nat. Mater. 2006, 5, 683-696. [CrossRef] [PubMed]

29. Cowan, S.R.; Banerji, N.; Leong, W.L.; Heeger, A.J. Charge formation, recombination, and sweep-out dynamics in organic solar cells. Adv. Funct. Mater. 2012, 22, 1116-1128. [CrossRef]

30. Blake, A.J.; Brooks, N.R.; Champness, N.R.; Cooke, P.A.; Nicolson, E.B.; Wilson, C. Multi-modal bridging ligands; effects of ligand functionality, anion and crystallisation solvent in silver(I) co-ordination polymers. J. Chem. Soc. Dalton Trans. 2000, 1, 3811-3819. [CrossRef]

31. Mamdouh, W.; Uji-I, H.; Ladislaw, J.S.; Dulcey, A.E.; Percec, V.; De Schryver, F.C.; De Feyter, S. Solvent controlled self-assembly at the liquid-solid interface revealed by STM. J. Am. Chem. Soc. 2006, 128, 317-325. [CrossRef] [PubMed]

32. Zhang, J.; Sun, Z.; Yang, B. Self-assembly of photonic crystals from polymer colloids. Curr. Opin. Colloid Interface Sci. 2009, 14, 103-114. [CrossRef]

33. Yamada, M.; Zhongrong, S.; Miyake, M. Self-assembly of discotic liquid crystalline molecule- modified gold nanoparticles: Control of $1 \mathrm{D}$ and hexagonal ordering induced by solvent polarity. Chem. Commun. 2006, 24, 2569-2571. [CrossRef] [PubMed]

34. Zhang, X.; Chen, T.; Chen, Q.; Deng, G.J.; Fan, Q.H.; Wan, L.J. One Solvent Induces a Series of Structural Transitions in Monodendron Molecular Self-Assembly from Lamellar to Quadrangular to Hexagonal. Chem. Eur. J. 2009, 15, 9669-9673. [CrossRef] [PubMed]

35. Lamann-Glees, A.; Ruschewitz, U. Effect of counteranions in self-assembled silver(I)-coordination polymers of 4-aminobenzonitrile. Cryst. Growth Des. 2012, 12, 854-861. [CrossRef]

36. Custelcean, R. Anions in crystal engineering. Chem. Soc. Rev. 2010, 39, 3675-3685. [CrossRef] [PubMed] 
37. Pradeep, C.P.; Longa, D.L.; Cronin, L. Cations in control: Crystal engineering polyoxometalate clusters using cation directed self-assembly. Dalton Trans. 2010, 40, 9443-9457. [CrossRef] [PubMed]

38. Carlucci, L.; Ciani, G.; Proserpiob, D.M.; Rizzato, S. New polymeric networks from the self-assembly of silver(I) salts and the flexible ligand 1,3-bis(4-pyridyl)propane (bpp). A systematic investigation of the effects of the counterions and a survey of the coordination polymers based on bpp. Cryst. Eng. Comm. 2002, 4, 121-129. [CrossRef]

39. Hirsch, K.A.; Wilson, S.R.; Moore, J.S. Coordination networks of 3,3'-dicyanodiphenylacetylene and silver(I) salts: Structural diversity through changes in ligand conformation and counterion. Inorg. Chem. 1997, 36, 2960-2968. [CrossRef] [PubMed]

40. Blake, A.J.; Brooks, N.R.; Champness, N.R.; Hanton, L.R.; Hubberstey, P.; Li, W.S.; Schroder, M. Copper(I) halide supramolecular networks linked by N-heterocyclic donor bridging ligands. Pure Appl. Chem. 1998, 70, 2351-2357. [CrossRef]

41. Min, K.S.; Suh, M.P. Silver(I)-polynitrile network solids for anion exchange: anion-induced transformation of supramolecular structure in the crystalline state. J. Am. Chem. Soc. 2000, 122, 6834-6840. [CrossRef]

42. Noro, S.; Kitaura, R.; Kondo, M.; Kitagawa, S.; Ishii, T.; Matsuzaka, H.; Yamashita, M. Framework Engineering by Anions and Porous Functionalities of $\mathrm{Cu}(\mathrm{II}) / 4,4^{\prime}$-bpy Coordination Polymers. J. Am. Chem. Soc. 2002, 124, 2568-2583. [CrossRef] [PubMed]

43. Bu, X.H.; Chen, W.; Hou, W.F.; Du, M.; Zhang, R.H.; Brisse, F. Controlling the framework formation of silver(I) coordination polymers with 1,4-bis(phenylthio)butane by varying the solvents, metal-to-ligand ratio, and counteranions. Inorg. Chem. 2002, 41, 3477-3482. [CrossRef] [PubMed]

44. Leininger, S.; Olenyuk, B.; Stang, P.J. Self-assembly of discrete cyclic nanostructures mediated by transition metals. Chem. Rev. 2000, 100, 853-908. [CrossRef] [PubMed]

45. Schnebeck, R.D.; Freisinger, E.; Lippert, B. A new twelve times positively charged anion receptor, that simultaneously incorporates $\mathrm{NO}_{3}{ }^{-}$and $\mathrm{PF}_{6}{ }^{-}$anions. Angew. Chem. 1999, 111, 235-238. [CrossRef]

46. Bassanetti, I.; Comotti, A.; Sozzani, P.; Bracco, S.; Calestani, G.; Mezzadri, F.; Marchiò, L. Porous molecular crystals by macrocyclic coordination supramolecules. J. Am. Chem. Soc. 2014, 136, 14883-14895. [CrossRef] [PubMed]

47. Caballero, A.; Maclaren, K.J.; Rodríguez-Diéguez, A.; Vidal, I.; Dobado, J.A.; Salas, J.M.; Janiak, C. Dinuclear silver(I) complexes for the design of metal-ligand networks based on triazolopyrimidines. Dalton Trans. 2011, 40, 11845-11855. [CrossRef] [PubMed]

48. Liu, Q.X.; Huo, R.; Liu, J.; Wei, Q.; Zhao, X.J.; Zhao, Z.X. NHC tetranuclear silver(I) complexes and intramolecular extended $\pi-\pi$ interactions. Organometallics 2015, 34, 3167-3174. [CrossRef]

49. Trivedi, M.; Singh, G.; Kumar, A.; Rath, N.P. Silver(I) complexes as efficient source for silver oxide nanoparticles with catalytic activity in $\mathrm{A}^{3}$ coupling reactions. Inorg. Chim. Acta. 2015, 438, 255-263. [CrossRef]

50. Zhang, T.; Mei, H.X.; Wang, D.F.; Huang, R.B.; Zheng, L.S. Syntheses, structures, thermal stabilities and photoluminescent properties of three silver(I) complexes of 2-ethyl-3-methylpyrazine and different aromatic dicarboxylates with various silver units. J. Mol. Struct. 2015, 1092, 44-50. [CrossRef]

51. Mujahid, M.; Kia, A.F.A.; Duff, B.; Egan, D.A.; Devereux, M.; McClean, S.; Walsh, M.; Trendafilove, N.; Georgieva, I.; Creaven, B.S. Spectroscopic studies, DFT calculations, and cytotoxic activity of novel silver(I) complexes of hydroxy ortho-substituted-nitro-2 H- chromen-2-one ligands and a phenanthroline adduct. J. Inorg. Biochem. 2015, 153, 103-113. [CrossRef] [PubMed]

52. Goitia, H.; Nieto, Y.; Villacampa, M.D.; Kasper, C.; Laguna, A.; Gimeno, M.C. Antitumoral gold and silver complexes with ferrocenyl-amide phosphines. Organometallics 2013, 32, 6069-6078. [CrossRef]

53. Reger, D.L.; Semeniuc, R.F.; Rassolov, V.; Smith, M.D. Supramolecular architecture of a silver(I) coordination polymer supported by a new ligand containing four tris(pyrazolyl)methane units. Inorg. Chem. 2004, 43, 537-554. [CrossRef] [PubMed]

54. Manzano, B.R.; Jalón, F.A.; Soriano, L.M.; Carrión, C.M.; Carranza, P.M.; Mereiter, K.; Rodríguez, A.M.; De La Hoz, A.; Sánchez-Migallón, A. Multiple hydrogen bonds in the self-assembly of aminotriazine and glutarimide. Decisive role of the triazine substituents. Inorg. Chem. 2008, 47, 8957-8971. [CrossRef] [PubMed]

55. Bassanetti, I.; Mezzadri, F.; Comotti, A.; Sozzani, P.; Gennari, M.; Calestani, G.; Marchiò, L. Influence of Anions in Silver Supramolecular Frameworks: Structural Characteristics and Sorption Properties. J. Am. Chem. Soc. 2012, 134, 9142-9145. [CrossRef] [PubMed] 
56. Janssen, F.F.B.J.; Laurens, P.J.V.; Smits, J.M.M.; De Gelder, R.; Rowan, A.E. 2. The multiple phenyl embrace as a synthon in $\mathrm{Cu}(\mathrm{I}) / \mathrm{PPh} 3 / \mathrm{n}$-donor ligand coordination polymers. Cryst. Growth Des. 2011, 11, 4313-4325. [CrossRef]

57. Sekiya, R.; Fukuda, M.; Kuroda, R. Anion-directed formation and degradation of an interlocked metallohelicate. J. Am. Chem. Soc. 2012, 134, 10987-10997. [CrossRef] [PubMed]

58. Noveron, J.C.; Lah, M.S.; Del Sesto, R.E.; Arif, A.M.; Miller, J.S.; Stang, P.J. Engineering the structure and magnetic properties of crystalline solids via the metal-directed self-assembly of a versatile molecular building unit. J. Am. Chem. Soc. 2002, 124, 6613-6625. [CrossRef] [PubMed]

59. Pederson, M.R.; Jackson, K.A. Variational mesh for quantum-mechanical simulations. Phys. Rev. B 1990, 41, 7453. [CrossRef]

60. Jackson, K.A.; Pederson, M.R. Accurate forces in a local-orbital approach to the local-density approximation. Phys. Rev. B 1990, 42, 3276. [CrossRef]

61. Pederson, M.R.; Jackson, K.A. Pseudoenergies for simulations on metallic systems. Phys. Rev. B 1991, 43, 7312. [CrossRef]

62. Quong, A.A.; Pederson, M.R.; Feldman, J.L. First principles determination of the interatomic force-constant tensor of the fullerene molecule. Solid State Commun. 1993, 87, 535-539. [CrossRef]

63. Porezag, D.; Pederson, M.R. Optimization of Gaussian basis sets for density-functional calculations. Phys. Rev. A 1999, 60, 2840. [CrossRef]

64. Pederson, M.R.; Porezag, D.V.; Kortus, J.; Patton, D.C. Strategies for Massively Parallel Local-Orbital-Based Electronic Structure Methods. Phys. Status Solidi 2000, 217, 197-218. [CrossRef]

(C) 2018 by the authors. Licensee MDPI, Basel, Switzerland. This article is an open access article distributed under the terms and conditions of the Creative Commons Attribution (CC BY) license (http:/ / creativecommons.org/licenses/by/4.0/). 